\title{
Cosi fan tutti i compositori: The Cephalus- Procris Myth and the Birth of Romantic Opera in Hoffmann's Aurora
}

\section{Citation}

Hamilton, J. T. 2013. “Cosi Fan Tutti i Compositori: The Cephalus-Procris Myth and the Birth of Romantic Opera in Hoffmann's Aurora." The Opera Quarterly 29 (2) (April 1): 88-100. doi:10.1093/ oq/kbt007.

\section{Published Version}

doi:10.1093/oq/kbt007

\section{Permanent link}

http://nrs.harvard.edu/urn-3:HUL.InstRepos:14068328

\section{Terms of Use}

This article was downloaded from Harvard University's DASH repository, and is made available under the terms and conditions applicable to Open Access Policy Articles, as set forth at http:// nrs.harvard.edu/urn-3:HUL.InstRepos:dash.current.terms-of-use\#OAP

\section{Share Your Story}

The Harvard community has made this article openly available.

Please share how this access benefits you. Submit a story.

\section{Accessibility}




\section{Così fan tutti i compositori: The Cephalus-Procris Myth and the Birth of Romantic Opera in Hoffmann's Aurora}

$\left\{\begin{array}{l}\text { JOHN T. HAMILTON } \\ \text { HARVARD UNIVERSITY }\end{array}\right\}$

Via, via passaro i tempi

Da spacciar queste favole ai bambini.

-Da Ponte/Mozart, Così fan tutte

The German Romantic call for a "new mythology"-for a return to a mythic sensibility that would revitalize a world desiccated by scientific revolutions, secularization, and presumed hyperrationalism - cannot be understood as implying that myth was wholly absent from the previous centuries. The most cursory review of eighteenth-century artworks would readily demonstrate that myths hardly failed to persist throughout the Age of Enlightenment. Rather, Romantic theorists were avid for a different relation to myth, arguing for the active production of meaning out of the hidden resources of the human imagination, for an original creation grounded in the self that would distinguish itself from the merely intellectual manipulation of inherited stories. According to Friedrich Schlegel, Romantic poets shared a fundamental problem that plagued writers of the prior era, namely a lack of an authentic mythology. Such was modernity's fate. Yet, whereas eighteenth-century artists tended to compensate for this deficit by applying ancient characters and plots to contemporary concerns, Schlegel believed that latter-day poets should plumb "the deepest depths of the spirit" in order to create fresh narratives.. Instead of employing classical myths to represent moral matters, the new mythology would, after Kant, gesture toward the noumenal origin of phenomenal existence and thereby aim toward achieving a lost unity of poetry and philosophy—-the "literary absolute." ${ }^{2}$

The force of Schlegel's theories is by now a familiar characteristic of all avantgarde movements, which betray an intention to destroy outmoded forms of expression in order to make way for the new. ${ }^{3}$ Around 1800 the first generation of German Romantic writers would elaborate this initiative: the former neoclassical 
adoption of a primarily Latin heritage, closely associated from Gotthold Ephraim Lessing onward with the French tradition, must be abandoned for a return to roots that would better (more originally, more authentically) express the singularity of cultural experience outre-Rhin. Accordingly, in Schlegel's Gespräch über die Poesie (180o), the adjective "classical" is nearly always pejorative, designating a falsifying poetics that would only cripple a nation's expressive potential-“a modern sickness" that might be cured by considering instead more specifically Germanic material from fairy tales, from the feudal Middle Ages, and the like. ${ }^{4}$

Nonetheless, Schlegel's lengthy dialogue curiously concludes with a move toward a classical theme. The text's final paragraph abruptly suggests that poets take up "the old story of Apollo and Marsyas [whose] time apparently has come" (scheint . . . an der Zeit zu sein). ${ }^{5}$ The sudden intrusion of a Greco-Roman myth is at first striking, especially given this story's frequent role in the predominantly Latinate discourse of the Renaissance. Yet this closing proposal is perfectly reconcilable with Schlegel's vision, provided one focuses on the implications of this eminently musical fable. If the neoclassical tradition would celebrate the victory of Apollo's rational lyre by extolling the instrument that easily accompanies, enhances, and ultimately serves lyric expression, the Romantic spirit would call for a rematch by siding with Marsyas's defeated woodwind: that is, with the aulos, whose fascinating, irregular, and dangerously alluring sound overrides verbal production. ${ }^{6}$ In brief, for Schlegel, it would seem that the time had come to reject Apollonian form in favor of the spontaneous, hyperventilated spiritus exuding from the ugly but impassioned satyr.

Schlegel's programmatic statements and their subscription to idealism's transcendental aspirations were more or less corroborated by Novalis and Friedrich Schelling and would come to be adopted and modified by E. T. A. Hoffmann, who relied on similar conceptions for his own theories of artistic inspiration. It was Hoffmann, moreover, who explicitly picked up on the Marsyan hint that closes Schlegel's Gespräch. For him, Romanticism's transcendental component was consistently allied to music, whose nonverbal properties were capable of irradiating quotidian experience. As Hoffmann famously formulated it in his seminal essay on "Beethoven's Instrumental Music" (1813), "Music reveals to man an unknown realm, a world quite separate from the outer sensual world surrounding him, a world in which he leaves behind all precise feelings in order to embrace an inexpressible longing." Hence, Schlegel's Romantic synthesis of poetry and philosophy yielded to Hoffmann's staged encounter between two distinct species of communication: verbal language, which communicates meaning; and music, which simply communicates itself. In this regard, Greco-Roman myths could again be inscribed within the Romantic program by exposing them to the intrusive, sublime power of music. Like Schlegel, Hoffmann understood this artistic achievement as a result of the collision of two discourses, which was defined as irony; in contrast to Schlegel, 
however, the ironic conflict was better conceived not as a clash within verbal language but rather between language and music, its nonverbal other.

Although Hoffmann's prose writings, beginning with his first publication, Ritter Gluck (1809), strove by way of irony to introduce musical disturbance, it is ostensibly his endeavors in opera where the collision of music and text could most forcefully be felt. Here the operatic theories enunciated by fantastic figures such as his Gluck could be put into practice. It is, I would argue, no small matter that his first attempt to compose what he styled as "a Romantic opera" is based on the Ovidian myth of Cephalus and Procris: Aurora, completed in Bamberg in 1812 with libretto by Hoffmann's theatrical associate Franz von Holbein. Tellingly, the opera opens with an episode of musical disturbance-Cephalus's seductive flute playing, which causes Procris to lose her way in a dark forest. The girl unwittingly leaves her company behind to approach the source of the enchanting melody that eventually becomes her own. The time for Marsyas, now armed with his Zauberflöte, indeed has come.

My light allusion to Mozart is not gratuitous. In his most sustained essay on operatic production, "Der Dichter und der Komponist" ("The Poet and the Composer," 1813), Hoffmann introduces the prolific master at a crucial moment. A quick review of the essay's main points would be useful. The dialogue staged between the poet Ferdinand and the composer Ludwig essentially grapples with a single issue: Given the general dissatisfaction among composers with the work of librettists and, conversely, acknowledging poets' consistent frustration regarding musicians' expectations, is it not preferable for the composer of an opera to write his own text as well? Ludwig's strict refusal to prepare his own libretto is based on composers' need to remain open to the flood of melodies pouring in from the "spirit realm" rather than be distracted by the bothersome search for appropriate words. ${ }^{8}$ Throughout, the ideal posited by Ludwig is "Romantic opera" - "the only true sort [of opera], for only in the realm of Romanticism is music at home" (196). Here it would be shown that the poet and the composer are "kindred members of one church; for the secret of words and sounds is one and the same, unveiling to both the ultimate sublimity" (195). "Let the poet be prepared for daring flights to the distant realm of Romanticism, for it is there that he will find the marvellous things that he should bring into our lives. Then, dazzled by their brilliant colors, we willingly believe ourselves as in a blissful dream to be transported from our meager everyday existence to the flowery avenues of that Romantic land, and to comprehend only its language, words sounding forth in music" (196).

Although Romantic opera receives the majority of the friends' attention, the discussion eventually turns to the topic of opera buffa. As Ferdinand gathers from Ludwig's descriptions, the comedic energy of opera buffa should not be opposed to ecstasy induced by Romantic opera. Rather, both are structurally analogous, for opera buffa depends on a "fantastic" element (eccentric behavior, bizarre twists, 
and so forth) that "invades everyday life and turns everything topsy-turvy" (202). That is to say, the fantastic aspect of opera buffa, with its intrusive and disorienting effects, simply takes the place of the Romantic quality that bears us from one realm to the next. ${ }^{9}$ Mozart's Cosi fan tutte is proffered as exemplary, insofar as it conveys "an impression of the most delicious irony"; and Ferdinand instantly understands how Da Ponte's “despised libretto of that opera is in fact truly operatic" (203).

In addition to redeeming Da Ponte's work, which would continue to be maligned throughout the nineteenth century for its cynicism and its libertinism, this gesture toward Cosi fan tutte provides hints to Hoffmann's own operatic endeavors: the plot of Da Ponte's "truly operatic" libretto may be understood as drawing from the same classical source as Holbein's text for Hoffmann's Aurora, namely Ovid's myth of Cephalus and Procris. The tale's central motif of the suspicious lover who appears disguised to test the faithfulness of his beloved clearly shapes Da Ponte's plot, albeit light-handedly. Ernst Gombrich, who was the first to call attention to this mythological provenance, plainly claims: "All da Ponte has done is to enrich the plot by the simple device of doubling the pair and replacing Aurora, who, in Ovid, incites Cephalus to this stratagem, by the philosopher Alphonso who makes it the object of a wager." ${ }^{\circ}$ From a Hoffmannian viewpoint the Mozart opera handles the myth's narrative form in a thoroughly "fantastic" (eccentric, bizarre) fashion, that is, without any of the preternatural and fairy-tale elements that Holbein would supply to transform the mythic material into a veritable Romantic opera. Whereas Da Ponte restricts his treatment to the all-too-human level by substituting a goddess with a cynical philosopher and a cheeky servant, Holbein reintroduces Aurora, which essentially amounts to a reenchantment of the old story. Hoffmann's Romantic opera therefore could serve as a useful illustration of how classical myth was staged for the new historical context of 1812 and made to attend to new aesthetic-generic intentions. In the following comparison of Ovid's text and Hoffmann's Aurora I attempt to specify the cultural and music-theoretical ramifications implicit in the myth's shifting functions.

$* * *$

The sorrowful story of Cephalus and Procris closes Book 7 of Ovid's Metamorphoses and belongs to a larger group of myths connected with Attica." Cephalus, an Athenian prince, has traveled to Aegina to beseech King Aeacus for military support to ward off Minos of Crete, who has waged war against Athens. Cephalus is promised Aeginitian aid and is prepared to return to his home city the following morning. However, when the "golden Sun" (aureus.... Sol) rises, a strong east wind (eurus) prevents setting sail $(7.663-64)$. The thwarted sea journey and the military backdrop give Cephalus the occasion to relate the tragedy of his earlier life with his wife Procris. In addition to linking the meteorological forces of facilitating 
sunlight and obstructing blasts, the paranomasia (aureus-eurus) already serves as an index to the goddess Dawn (Aurora), whose role as both facilitator and obstructionist will soon become manifest. Unable to depart, Cephalus retires to the palace, accompanied by Aeacus's son Phocus, who immediately marvels at the Athenian's peculiar javelin with the "golden spearhead" (aurea cuspis, 673). Even before we learn of the weapon's dreadful history, the epithet aurea inscribes it into the signifying chain of assistance and hindrance. Cephalus's response confirms our suspicions: the javelin strikes every target without fail; yet this trusty missile is also that which “makes him weep" (683, 691). Ambivalence, together with its relation to morphemic confusion, will contaminate the entire narrative and ultimately serve as its principal theme.

Cephalus's tears are for Procris, his departed wife, who surpassed all in beauty. Only two months after their marriage, Cephalus was out hunting at dawn when Aurora spotted the young man and instantly "ravished [him] against his will" (invitumque rapit, 704). Despite the goddess's undeniable charms, Cephalus still asserted his love for Procris alone. Angered by his resistance, Aurora foretold that he would wish he had not made such a choice. This prediction came to haunt Cephalus as he made his way back home. Now suspecting Procris of unfaithfulness, Cephalus decided to test his bride; and Aurora, who was well disposed to this plan, assisted him by changing his appearance. Disguised as a stranger, Cephalus attempted to seduce Procris, who persisted in her loyalty to her husband. When she hesitated for one brief moment, however, the suspicious examiner revealed himself and lashed out, pained by his victory (male victor, 741). Overwhelmed by shame, Procris fled immediately into the forest, devoting her life to the goddess Diana. With his incessant pleas and self-accusation, Cephalus eventually received pardon from Procris, and the couple resumed their happy life together. To seal their reconciliation, Procris offered her husband two gifts that came from Diana: a wondrously speedy hound and the fascinating javelin, which Cephalus carries to this day.

Ambivalence was soon reasserted. Cephalus describes the "joys" of this renewed marital bliss as the "beginning of his sorrow" (gaudia principium... doloris, 796). It was the young man's custom to recover from a long day of hunting by retreating to the coolness of the shade, where he would longingly summon the refreshing breeze (aura). An unnoticed eavesdropper, whose "ear was deceived by the ambiguous words" (vocibus ambiguis deceptam . . a aurem, 821), assumed that Cephalus was calling upon a nymph named Aura and straightaway informed Procris of the suspected adultery. The roles were now completely reversed, for it was the wife who suffered from suspicions and decided to test her husband by tracking behind him during the next morning's hunt. “After the Dawn's light banished the night" (postera depulerant Aurorae lumina noctem, 835), Cephalus entered the woods, rested upon a clearing, and called out for the comforting breeze-aura, veni! (837). At that precise moment a rustling was heard from behind. Cephalus 
hurled his fail-proof javelin before he realized that it was Procris who was the unfortunate target. As she passed away, she entreated her husband not to allow "Aura" to take her place in their bed; "and then at last [he] both perceived and learned it was an error in the name" (et errorem tum denique nominis esse / et sensi et docui, 857-58) that was responsible for the tragedy.

More precisely, the narrative is understood as having been motivated by misunderstandings caused by a word's overdetermination, which Ovid specifies throughout as an effect of audition. From beginning to end, the plot's key verbal components join together to produce an ambiguous, quasi-musical resonance that impels the painful story to its fateful end: aureus. . eurus. . aurea. . . Aurora ...aura...aurem-the "golden" Sun that permits safe navigation and the "east wind" that renders it dangerous; the "golden" spearhead that is both beneficial and malevolent; Aurora, the goddess who hunts down Cephalus as well as the dawn that signals his own expeditions; and Aura, both the breeze that refreshes and the phantasmatic nymph who arouses suspicion in the "ear" of the unintended audience. It is as though Ovid already recognized how the phonic aspect of speech intrudes upon semantic intent. Hoffmann, following Schlegel, would identify this "error" or "wandering" of names (error nominis) as the irony that defines the very earmark of Romanticism.

$* * *$

A long and complex reception history separates Ovid's presentation of Cephalus and Procris from Holbein's adaptation. In addition to the allegorical interpretations popularized since the fourteenth century by the Ovide moralisé, the librettist would have recourse to various treatments from early modern literature: for example, from Boccaccio's De claris mulieribus (1374), Niccolò da Correggio's Favola di Cefalo (1487), and Lope de Vega's La bella Aurora (1635). ${ }^{12}$ The earliest extant Spanish opera, Celos aun del aire matan, composed around 1660 by Juan Hidalgo with a libretto by Hoffmann's beloved Calderón de la Barca, borrows liberally from the Cephalus myth and thereby stands as a significant source. In fact, the myth occurs frequently in Europe's earliest operas: Il rapimento di Cefalo by Giulio Caccini to celebrate the wedding of Henri IV of France and Marie de' Medici in 1600, just days after the premiere of Jacopo Peri's Euridice; and L'Aurora ingannata by Girolamo Giacobbi, the first opera performed in Bologna in 1605. The subject matter would continue to appear in productions throughout the seventeenth and eighteenth centuries. ${ }^{13}$ Although some of this material was at Holbein's disposal, a review of his plot will quickly show that he drew from an entire range of classical and modern motifs to enhance the Ovidian tale.

A number of innovations closely link Holbein's text to a pastoral tradition: whereas Ovid introduces Cephalus as an Athenian prince and avid hunter, Holbein 
portrays him as an unnamed, poor shepherd-his true identity as Cephalus will only emerge at the opera's end. Moreover, while Ovid's couple is already married before the story opens, Holbein simply gives us two young people meeting for the first time and falling deeply in love. Clearly a notion of youthfulness was important for Hoffmann, since he composed the part of Cephalus for mezzo soprano. ${ }^{14}$ That the opening scene presents Cephalus upon the steps of Diana's temple and Procris on a hunt further implies a reversal of Ovidian roles. What precisely motivates these modifications of the classical myth?

The plot of the first act revolves around marriage plans for Procris. ${ }^{15}$ Her father, King Erechtheus, has publicly consigned her to Dejoneus, the old king of Phocis. However, Erechtheus's general Polybius makes his own bid for Procris's hand, based on a prior promise by which the king would grant whatever the general wished. The father is therefore compelled to present his daughter with a choice between the two men, even though he fears that humiliation might drive Dejoneus to war. When Procris arrives home from her hunting expedition, having already pledged eternal fidelity to the anonymous shepherd, she is distraught by the decision now facing her. Harried by her father's impatience, she confides to Polybius of her love for the shepherd, and the general ultimately swears to help the girl, whom he now regards as a beloved daughter. Polybius instructs Procris to select him for now but does not divulge any more of the stratagem. In the finale to the first act, Procris follows the plan and selects Polybius. Cephalus, who has been hiding in the background, now appears suddenly among the crowd. Never having been apprised of the ruse, he desperately moves to throw himself upon his sword, but Procris runs to save him. Amid the confusion, the people of the court and the attendant priests demand the immediate execution of the audacious stranger, and it is Polybius who steps forward to lead the criminal away.

Holbein thus deviates greatly from Ovid's narrative, which mentions nothing of a marriage contest. He retains the threat of war, posed by Minos in the Metamorphoses, but assigns this role to Dejoneus, whose motivation is explicitly personal and grounded in public insult. Still, Holbein's portrayal is not as distant from his Ovidian source as it may first appear. It is noteworthy that the librettist borrows freely from other Ovidian episodes to drive his plot: the exchange between Polybius and Erechtheus cannot fail to recall the encounter in Book 2 of the Metamorphoses between the Sun (Sol) and his son Phaethon, who desires to steer the fiery chariot across the sky. In Holbein's text, the general's reminder of a past promise and the king's troubled reply ("Fordere alles, nur verlange nicht . . ."-Ask anything, only do not demand . . . . I.4) rehearses the Sun's response to his overambitious son: "Ask anything, but I plead that you not ask this one thing" (posce . . aliquid . . . / deprecor hoc unum . . . / poscis! Met. 2.97-99). Holbein's allusion to this memorable scene effectively opens up Ovid's text to its latencies: we recall that in Book 7 it is the "golden Sun" (aureus Sol) who summons Cephalus to set sail at the start of the 
episode. By pressing an allusion back to the personification of Sol in Book 2, Holbein allows the Sun to be characterized as an anxious father; and it is this characterization that is made to bear on Holbein's operatic portrayal of Erechtheus. Moreover, in turning to the Phaethon story, we espy Aurora's glow, which signals the start of the daytime journey (effulget tenebris Aurora fugatis, 2.144). Rather than strictly adhere to Ovid's plotline, Holbein, presumably under Hoffmann's direction, pursues Ovidian resonances to enhance a fresh narrative. ${ }^{16}$ This "intratextual" device is well-aligned with Hoffmann's Romantic intentions, for it disrupts the linear flow of Ovid's narrative by allowing other instances of the poem to intrude upon the action.

In a similar fashion, when Cephalus is escorted by Polybius to the temple of Aurora at the start of the second act, the shepherd learns of the goddess's unhappy love for Tithonus, which amply employs material from Ovid's Amores (1.13). Here Aurora is presented in an unequivocally sympathetic light, which persists throughout the opera. Although she has fallen in love with Cephalus, she ultimately promises to help and protect him rather than behave angrily against him. The goddess camouflages the shepherd as a prince, not to test Procris's fidelity but rather to make his marriage bid. Perhaps the clearest instance of the way Aurora romantically splits open the Ovidian myth is in the opera's third act, where we learn that the shepherd is in fact the lost son of King Dejoneus. Dejoneus exposed the newborn after an oracle proclaimed that "the son would one day tear what is dearest from the father" (Das Teuerste wird dem Vater einst der Sohn entreißen, III.1). The prophecy was interpreted as referring either to "matricide" or "usurpation" (Muttermord or Kronenraub), and so the infant's murder was ordered. Again, this insertion of the Oedipal family romance is not merely free invention but rather picks up on a hint occurring in the midst of Ovid's Cephalus myth. After the couple is reunited, mention is made of the "son of Laius" who solved the Sphinx's riddle (7.759). As before, Holbein takes this brief allusion as the occasion for transforming the myth from within.

The function of intrusion within the libretto corresponds with intrusions on the level of Hoffmann's composition. The most obvious device is the use of identifiable musical themes, such as the passage that signals Aurora's presence or the one that recalls the resounding columns of her temple. This clear anticipation of the Wagnerian leitmotif consistently produces the Romantic effect of being transported out of the represented scene. Through this method, Hoffmann underscores the fracturing of the myth's delineation-not, however, with an aim toward fragmentation but rather toward a greater unity, toward the realization of a higher source. The desire to achieve this transcendent unity-an aspiration that is explicitly and repeatedly formulated by Hoffmann in his musical writings-is paradoxically confirmed by the preference for dividing the operatic labor between a librettist and a composer, which is the main argument of "The Poet and the Composer" essay. 
It is significant that Hoffmann prepared "The Poet and the Composer" in 1813, a year after completing Aurora. As in the Cephalus myth, the menace of war is never distant: the advances of Minos's navy in Ovid and Dejoneus's wrathful threats in Aurora correlate to the historical context of the Napoleonic Wars. First published in the Allgemeine Musikalische Zeitung, the essay was later included in the first volume of Hoffmann's Die Serapions-Brüder collection of 1819 . In this revision, he appended a prologue that reinforces the constitutive circumstances of war. Thus, although the essay's title promises an aesthetic discussion of the relation between words and music, it curiously opens with a rather unexpected, ominous tone: “Der Feind war vor den Toren" (The enemy was at the gates, guns thundered all around, and grenades cut through the air, sizzling amid showers of sparks). ${ }^{17}$ The threat here is explicitly audible (the "guns thundered"; the "grenades [were] sizzling"). Hoffmann's opening sentence portrays this military attack specifically as an assault on the ears. Expecting music, the reader is instead greeted with gunfire.

The reference is to the devastating Battle of Dresden in late August 1813 (which Hoffmann himself witnessed), where Napoleon was ultimately victorious against a formidable coalition of Russian, Prussian, and Austrian forces. Just prior to the outbreak of violence, Hoffmann had fled to Dresden, which remained in French hands. Soon after his arrival into the city, Napoleon's troops and the Allied forces were already beginning to mobilize. One would think that the disruptive atmosphere of the Saxon capital poised for warfare would be detrimental to Hoffmann's compositional work. However, Hoffmann appears to have found the noise, mayhem, and even danger to be altogether conducive to creative work. To his friend and future publisher, Carl Friedrich Kunz, he described the horrors and evil of war but also admitted some benefit: "At no other time has writing so appealed to me as in this dark and fateful time [in dieser düstern verhängnisvollen Zeit], when an existence has to be eked out and enjoyed from day to day. It is as if I unlocked for myself a marvelous realm coming forth from my inner self which, in taking shape, removes me from the pressures of life outside." 18 With ears unplugged, Hoffmann thus found security within the safe house of his imagination. The encroaching danger seemed to motivate rather than hinder creativity. Indeed, for Hoffmann, disruptive noises were the occasion not for alarm, but rather for marshaling one's inner strength and focusing power.

Nonetheless, "The Poet and the Composer" introduces the character Ludwig as being hard of hearing-like his famous Viennese namesake, he is deaf to the outside world. Amid the fearful noise of warfare, Ludwig sits quietly in his garret, "completely absorbed and lost in the wonderful, brightly colored world of fantasy that unfolded before him at the piano." ${ }^{19}$ Detached from the harsh reality just outside his window, he has finished a great symphony. Although the composer may 
believe that he is protected from all outside influence, Hoffmann's narrative reminds the reader of at least two areas of vulnerability. The first is the obvious, physical threat: no matter how well Ludwig ignores the ensuing battle, the danger remains inescapable. The unwitting composer stares at his landlady, who pleads that he take cover; but it is only when a shell crashes through the roof over his study that he grabs his beloved score and heads for the cellar. The second threat is less obvious, signaling a danger not from without but rather from within: we read how Ludwig struggles to notate the "divine language" of that "far, romantic realm," which impedes upon his consciousness. Throughout, as elsewhere in Hoffmann's texts, inspiration is characterized as an assaulting, painful force that arrives "to penetrate our narrow, paltry lives, and with sublime siren voices tempt forth its willing victims." ${ }^{20}$ Hoffmann's vocabulary is telling, insofar as its portrayal of attack and victimization places the penetrating power of music in close analogy with the military forces penetrating the city's fortifications. Just as Ludwig's body is exposed to the danger of deafening bombardment, so is his imagination open to the onslaught of heavenly resonance.

We might conclude that the spiritual invasion of inspiration beneficially leads to the composition of a symphony, whereas a bombing raid could only result in devastation. Hoffmann presses the analogy, however, to show that war can have beneficial effects as well. In the cellar where the household has gathered to protect itself, we read of the altering power of real, physical danger: "Their agitation and distress were soon transformed into that agreeable state in which we seek and fancy we find security in neighborly companionship. . . . Tenants who scarcely raised their hats when meeting on the stairs sat arm in arm beside each other, revealing their innermost feelings in mutual warmheartedness." (190)

With this description, Hoffmann appears to anticipate Friedrich Nietzsche, the philosopher of insecurity and a musician in his own right, by confirming the correlation between the way music and mortal danger assails and thereby transforms our quotidian narrowness. The analogy becomes even further evident within the dialogue itself when, as we have seen, Ludwig confesses to the poet Ferdinand an especial fondness for opera buffa in modern costume: "Here a sense of the fantastic . . . boldly invades everyday life and turns everything topsy-turvy" (202). In other words, the fantastic, like its analogue the Romantic, de-secures.

The ramifications, however morally questionable, still stand: the insecurity that war imposes upon us is doubtlessly horrific, but it may in the end foster a renewal of art. This thesis may serve as a commentary on Ovid's military framing of the Cephalus myth - if Minos had not posed a threat against the Athenians, we may never have heard the elegiac story of the prince's life with Procris. As for Hoffmann's dialogue, the conclusion is unambiguous on this point. Ludwig is about to discuss Mozart's Die Zauberföte, when a call to arms is sounded from the street outside. The loud alarm interrupts the conversation. The composer clasps the 
poet's hand and cries out, "What is to become of art in our harsh and turbulent times? Will it not perish, like a delicate plant that turns its drooping head in vain towards the dark storm-clouds behind which the sun has vanished?" (207) Ludwig, whose symphonic aspirations required a shutting out of the world, is compelled to admit that one must reckon with reality. For composers of purely instrumental music, it is a sorry fact that seems to foretell the end of art. Ferdinand, however, who has already grabbed his saber and helmet, corrects Ludwig's debilitating despair:

Ludwig, what has become of you? Has the prison air that you must have been breathing here for so long corroded your spirit so deeply that you are now too weak and ill to feel the warming breath of spring that plays outside among the clouds glowing in the golden dawn? . . L Ludwig, a fateful time is upon us. As though from the gloomy depths of ancient legends that echo down to us like miraculous rumblings of thunder from the distant twilight, we hear again the unmistakable voice of eternal omnipotence; bursting visibly into our lives it awakens in us the faith by which the mystery of our existence is disclosed. The dawn is breaking; enraptured voices rise into the fragrant air proclaiming godliness and praising it in song. (207-208)

Ferdinand's remarks reiterate the lesson drawn from the cellar scene in the opening frame narrative. Ludwig's sole attention to the pure realm of music purchases a security that may be likened to a prison sentence. It is a state of immunity in Roberto Esposito's sense, a protection of life that entails a negation of life, quite different from the notion of community, which is displayed among the warmhearted neighbors. ${ }^{21}$ Within his cell, Ludwig can certainly produce a symphony of worth, but never an opera. For that, he would need input from the real world, from a source external to himself, in the form of the more mundane language of words. In Hoffmann's aesthetic theory, opera alone is capable of rendering the spirit realm relevant, while disclosing the transcendent qualities of the real. Both the poet and the composer strive for the same ideal, but from different ends. The fact that Hoffmann presents his poet as a military officer is for this reason altogether telling.

For Ferdinand, the artillery's thundering is the sound that announces the coming of dawn. His repeated references to “dawn” readily allude to Hoffmann's Aurora, which is replete with similar evocations of sounds that solicit and obstruct determination. It is precisely Hoffmann's musical depictions of natural phenomena-of night, sunset, a plashing brook, a forest's rustling - that would become a staple of Romantic style. ${ }^{22}$ On a technical level, the opera's harmonic textures are especially noteworthy for their frequent and bold modulations. In another essay, entitled "On a Remark of Sacchini's, and on So-called Effect in Music" and dating from roughly the same period, Hoffmann extols the daring use of unexpected modulations, which he credits with the power to create "dramatic momentum." 23 In this essay, Hoffmann's example is the famous duet from the second act of Mozart's Don Giovanni, "O statua 
gentilissima," where the Commendatore's frightening "Sì," sung on the tonic E, is immediately redirected by Leporello, who sings the same E, but now as the third against the orchestra's $\mathrm{C}$ major, causing what Hoffmann describes as "the moment of greatest tension" (153). Aurora is filled with such effects. Indeed, in the opera's central number, the very same harmonic contrast between $\mathrm{E}$ major and $\mathrm{C}$ major forcefully marks Aurora's first entrance onto the stage (no. 8).

Irradiating the words with the unsettling harmonies of pure music, the opera repeatedly disrupts transcendence with the denotative concreteness of verbal art. The operatic listener is called upon to locate the key centers as well as locate the libretto's import; the same listener, however, is invariably frustrated in securing a place of unambiguous meaning. Securing a location-be it an immanent cause for the music or a transcendent cause for the text-would spell silence. Instead, for Hoffmann, the Romantic effect must be maintained in its infinitude-as unlocalizable as war is unforeseeable, founding a fragile community of the insecure, whose basis can only ever be unsure, unstable, and improvised. If Ovid's Cephalus myth relates the tragic effects of ambivalence, namely how the javelin given in love destroys the beloved, Hoffmann's “great Romantic opera” demonstrates how destructive forces can yield a triumph of love. In Ovid's text, the lonely narrator concludes in tears and must prepare for battle:

Flentibus haec lacrimans heros memorabat, et ecce

Aeacus ingreditur duplici cum prole novoque

milite; quem Cephalus cum fortibus accipit armis.

(Met. 7.863-65)

The hero related this crying with tears, and behold

Aeacus entered with both of his sons and his new

troop, which Cephalus received with their strong weapons.

In contrast, for the finale to Hoffmann's opera, the chorus sings of the "omnipotence of Love" (die Allmacht der Liebe):

Verbannt aus dem liebenden Busen

Der Selbstsucht verderblichen Wahn,

Und lobet und preiset die Liebe,

Die alles, was göttlich ist, kann!

Banish from your loving breast

The baneful delusion of selfishness,

And praise and extol Love,

Which can do all that is divine! 
NOTES

John T. Hamilton is professor of Comparative Literature and Germanic Languages and Literatures at Harvard University. Book publications include Soliciting Darkness: Pindar, Obscurity, and the Classical Tradition (Harvard University Press, 2004), Music, Madness, and the Unworking of Language (Columbia University Press, 2008), and Security: Politics, Humanity, and the Philology of Care (Princeton University Press, 2013).

1. Friedrich Schlegel, Gespräch über die Poesie (1800) in Kritische und theoretische Schriften, ed. Andreas Huyssen (Stuttgart: Reclam, 1978), 190. For a comprehensive historical account in English, see George Williamson, The Longing for Myth in Germany: Religion and Aesthetic Culture from Romanticism to Nietzsche (Chicago: University of Chicago Press, 2004), 19-71.

2. I am referring to the critical work of Philippe Lacoue-Labarthe and Jean-Luc Nancy, The Literary Absolute: The Theory of Literature in German Romanticism, trans. Philip Barnard and Cheryl Lester (Albany: State University of New York Press, 1988). Originally published as L'absolu littéraire: Théorie de la littérature du romantisme allemand (Paris: Seuil, 1978).

3. For a general overview in English, see Howard Hugo, "An Examination of Friedrich Schlegel's 'Gespräch über die Poesie,'” Monatshefte 40 (1948): 221-31.

4. Schlegel, Gespräch über die Poesie, 170.

5. Ibid., 224.

6. The ramifications of the Apollo-Marsyas contest have a long and complex history that cannot be engaged here. I have treated some of the issues involved in Music, Madness, and the Unworking of Language (New York: Columbia University Press, 2008), 35-48.

7. E. T. A. Hoffmann, “Beethoven's Instrumental Music," in E. T. A. Hoffmann's Musical Writings, ed. David Charlton (Cambridge: Cambridge University Press, 2003), 96.

8. E. T. A. Hoffmann, "The Poet and the Composer," in E. T. A. Hoffmann's Musical Writings, 193. The German text may be found in E. T. A. Hoffmann, Sämtliche Werke, 6 vols., ed. Hartmut Steinecke (Frankfurt: Deutscher Klassiker, 1993), 1:752-75.
9. Cf. Aubrey Garlington, “E. T. A. Hoffmann's 'Der Dichter und der Komponist' and the Creation of the German Romantic Opera," Musical Quarterly 65 (1979): 22-47.

10. Ernst H. Gombrich, "Così fan tutte (Procris included)," Journal of the Warburg and Courtauld Institutes 17 (1954): 372. Gombrich's reading has since been challenged and modified by Andrew Steptoe, "The Sources of Cosi fan tutte: A Reappraisal," Music Q Letters 62 (1981): 281-94.

11. On the significance of this broader context, see Viktor Pöschl, "Kephalos und Prokris in Ovids Metamorphosen," Hermes 87 (1959): 328-343.

12. For an extensive overview, including a consideration of the visual arts, see Irving Lavin, "Cephalus and Procris: Transformations of an Ovidian Myth," Journal of the Warburg and Courtauld Institutes 17 (1954): 260-87.

13. For a fairly comprehensive list, see Hermann Dechant, E. T. A. Hoffmanns Oper "Aurora"

(Regensburg, Germany: G. Bosse, 1975), 2-4. 14. Cf. ibid., 12.

15. The score consulted is E. T. A. Hoffmann, Aurora: Grosse romantische Oper, ed. Hermann Dechant (Wiesbaden: Breitkopf \& Härtel, 1984). All translations from the libretto are mine.

16. On Hoffmann's collaboration with Holbein, see Hermann Dechant, "Entstehung und Bedeutung von E. T. A. Hoffmanns Oper Aurora," Mitteilungen der E. T. A. Hoffmann-Gesellschaft 31 (1985): 6-14.

17. Hoffmann, "The Poet and the Composer," 189-90.

18. E. T. A. Hoffmann to Carl Friedrich Kunz, August 19, 1813, in Sämtliche Werke, 1:301. Published in English in Selected Letters of E. T. A. Hoffmann, trans. Johanna C. Sahlin (Chicago: University of Chicago Press, 1977), 202-3 (trans. modified).

19. Hoffmann, "The Poet and the Composer," 190.

20. Ibid.

21. See Roberto Esposito, Immunitas: Protezione e negazione della vita (Turin: Einaudi, 2002), 9-11.

22. For a musicological analysis, see Dechant, "Entstehung und Bedeutung," 13.

23. Charlton, E. T.A. Hoffmann's Musical Writings, 153. 